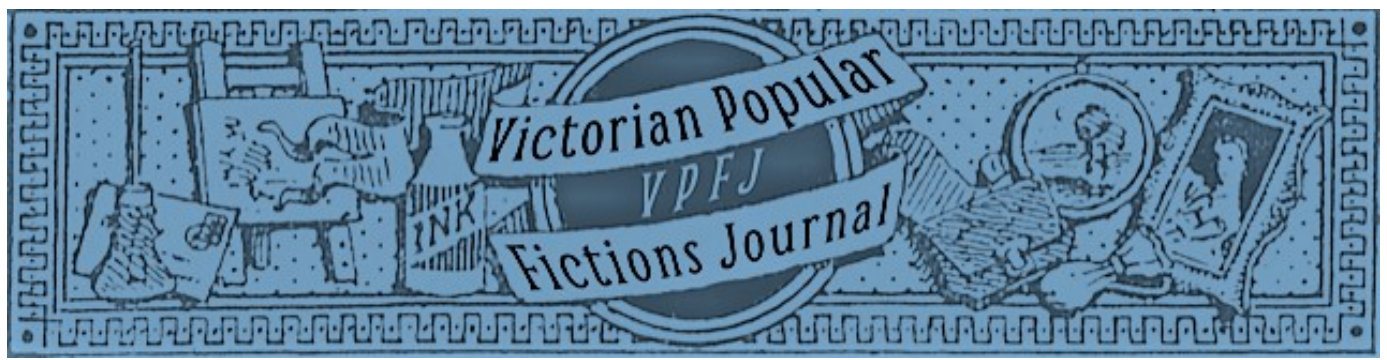

\title{
Sweeney Todd's Indian Empire: Mapping the East India Company in The String of Pearls
}

\author{
Rebecca Nesvet
}

\begin{abstract}
The myth of Sweeney Todd emerged from Victorian popular fiction, first appearing in the 1846-7 serial The String of Pearls, A Romance, now generally attributed to James Malcolm Rymer. By 1970, when Christopher G. Bond's Sweeney Todd, the Demon Barber of Fleet Street premiered at the avant-garde Theatre-Royal Stratford East, Sweeney Todd was firmly established as an urban legend. Modern adaptations of this myth are uniformly set in an ahistorically insular "Dickensian" London, while modern scholarship tends to focus on metropolitan cultural concerns. However, Maisha Wester (2015) demonstrates that The String of Pearls exploits fears of England's transformation by colonial outsiders by featuring exotic colonial locations and transposing the apocryphal Scottish villain Sawney Beane, spectre of xenophobia, to London. Building upon this reading, I argue that The String of Pearls depicts, in cartographically imaginable terms, the aftermath of the Anglo-Mysore Wars, which the private army of the British East India Company (EIC) fought against two successive rulers of the Indian kingdom of Mysore. Rymer's allusion to this conflict facilitates a critique of the EIC's practices that Rymer assumes his predominantly working-class reading audience will recognise and that evidently unnerved later adaptors and critics.
\end{abstract}

\section{Key words}

Sweeney Todd; James Malcolm Rymer; The String of Pearls; Tipu Sultan; Mysore; India; East India Company; imperialism; war; cartography; mapping.

Date of Acceptance: 23 December 2019

Date of Publication: 31 December 2019

Double Blind Peer Reviewed

\section{Recommended Citation:}

Nesvet, Rebecca. 2019. "Sweeney Todd's Indian Empire: Mapping the East India Company in The String of Pearls." Victorian Popular Fictions, 1.2: 75-90. ISSN: 2632-4253 DOI: https://doi.org/ 10.46911/GVBL6476

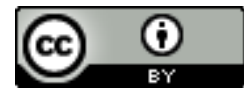

This work is licensed under a Creative Commons Attribution 4.0 International License. 


\section{Sweeney Todd's Indian Empire: Mapping the East India Company in The String of Pearls}

\section{Rebecca Nesvet}

The myth of Sweeney Todd emerged from Victorian popular fiction, first appearing in the 18467 serial The String of Pearls, A Romance, now generally attributed to James Malcolm Rymer. ${ }^{1}$ By 1970, when Christopher G. Bond's Sweeney Todd, the Demon Barber of Fleet Street premiered at the avant-garde Theatre-Royal Stratford East, Sweeney Todd was firmly established as an urban legend. As fantasy writer Neil Gaiman notes, this legend continues to appeal to Londoners and Londonphiles because it "seem[s] a beautiful way of talking about Fleet Street, about London, about the nature of London" (Carroll 1997, quoted in Mack 2007b: 82-3). Lending credence to Gaiman's theory, much recent criticism of The String of Pearls focuses on what this text has to say about London. Robert L. Mack's 2007 edition of The String of Pearls, published by Oxford University Press as a tie-in with Tim Burton's Hollywood film, includes a map of the Temple Bar area with a selection of locations from the text (Mack 2007a: xxxvii). Nothing beyond central London is visible, giving the impression that Sweeney Todd's London is an insular realm. More recently, Ted Geier argues that The String of Pearls is an obvious example of the nineteenth-century tendency to "paint a gruesome and dirty picture of London and the modern consumer society" wherein homo sapiens is dehumanised, legislated out of visibility, processed and consumed by the "bureaucratic" metropolis (Geier 2016: 2-4, 120). Rohan McWilliam asserts that "the location of The String of Pearls is Fleet Street ... giving the tale an alarming authenticity" (McWilliam 2019: 206). However, charting the major locations

\footnotetext{
${ }^{1}$ Throughout the twentieth century, The String of Pearls was attributed to Thomas Peckett Prest (181059) and/or James Malcolm Rymer (1814-84). The attribution to Prest seems to derive from a speculative quip published by the often inaccurate George Augustus Sala in the question-and-answer column of Sala's Journal in 1892. As Helen R. Smith has diplomatically put it, "Sala's later[-career] recollections require closer examination" than they have received because "they seem designed entirely to amuse," with no regard for truth (Smith 2019: 46). Today, bibliographic work done by Smith (2002) has caused a broad consensus of critics to accept Rymer as the author of The String of Pearls. As Dick Collins (2010), who unearthed further evidence tying the text to Rymer, declares, "the case" for Rymer's authorship "seems proven" (Collins 2010: xiii). More recently, firm attributions to Rymer can be found in Marie Léger-St-Jean's magisterial bibliographic database Price One Penny: A Database of Cheap Literature, 1837-1860 and Sarah Louise Lill and Rohan McWilliam's 2019 edited volume on Lloyd and his staff writers. See, for example, the essays in Lill and McWilliam by Smith (especially 39-40), Louis James (68), and Sara Hackenberg. McWilliam discusses The String of Pearls as an "anonymous" work, claiming that it does not matter which of Lloyd's staffers wrote it because they ultimately answered to him (198), but no recent scholarship makes a positive claim for Prest as the author. Additional primary evidence supporting the attribution to Rymer includes a précis published in a periodical that Rymer edited and largely composed, the London Miscellany (1866), of the 1824 Tell-Tale story universally accepted as a source for The String of Pearls, "The Murders in the Rue de la Harpe" ("Curiosities of Crime" 1866: 239). It is on these grounds that I accept the attribution to Rymer.
} 
and character journeys depicted in The String of Pearls reveals a plot surprisingly unconstrained by the boundaries of the London $A-Z$. Maisha Wester demonstrates that The String of Pearls features locations outside the city, in colonial spaces such as the Atlantic and Indian Oceans. According to Wester, The String of Pearls transposes the apocryphal Scottish villain Sawney Beane to London subtly to exploit fears of "the corrosion and erasure of Englishness at the hands of colonial subjects," including Irish, Asian, and African people (Wester 2015: 160).

Building upon Wester's reading, I observe that The String of Pearls not only explores the relationships between the metropolis and the colonial frontier but depicts the latter cartographically, imagining its Indian and African locations as if they were plotted on a map and expecting readers to do the same. Furthermore, Rymer situates The String of Pearls at a particular moment in the history of British imperialism: the Anglo-Mysore Wars, which the private army of the British East India Company (EIC) fought against two successive rulers of the Indian kingdom of Mysore, Haider Ali (r. 1761-82) and his son Tipu Sultan (r. 1782-99). Rymer's plotting of The String of Pearls on a map of this conflict facilitates a critique of the EIC's practices and those of corporations like it; a critique that Rymer assumes his predominantly working-class reading audience to recognise. This expectation proves justified, because later contributors to the Sweeney Todd transmedia tradition, evidently uncomfortable with the source text's topical critique, increasingly efface its Indian settings and, with them, the EIC controversy. This erasure, a kind of mapping that popular culture performs, ultimately relocates the Sweeney Todd legend to the insular imaginary London with which it is now strongly associated.

\section{Imperial Places, Spaces, and Time}

As Wester points out, although most of the action of The String of Pearls takes place in or near London, its backstory is decidedly imperial in scope and theme. Heroine Johanna Oakley's troubles begin when her fiancé Mark Ingestrie is seduced by imperialism's promises of easy wealth and social mobility. His "imagination" is "inflamed" by a man from outside London who has come to the city "with a well-authenticated and extremely well put together report" that "in one of the small islands near the Indian seas" a river runs with gold (Mack 2007a: 45). The tale captivates a group of London speculators ("some influential men - on account of the money they possessed"), inspiring them to launch a gold-extraction expedition; one speculator sends Ingestrie in his stead, promising him a "share in the proceeds" (Mack 2007a: 46). En route to the island, Ingestrie acquires the eponymous pearls, implicitly by stealing them, as he has no means with which to purchase them. Later, the expedition's ship, the Star, sinks in the Indian Ocean (figure 1, node 1). By this point, Ingestrie has given the pearls to a fellow speculator, Thornhill, in trust for Johanna, having a "strong ... presentiment" that he himself would die (Mack 2007a: 50). Colonel Jeffery "of the Indian Army" (the EIC army, Mack 2007a: 22) learns Ingestrie's story because his warship, the Neptune, returning from India, intercepts the sinking Star and rescues Thornhill and his dog (figure 1, node 2). From this point onwards, the fates of Ingestrie, his imperial jewels, his expedition, and the EIC officer Jeffery are inextricably intertwined. 


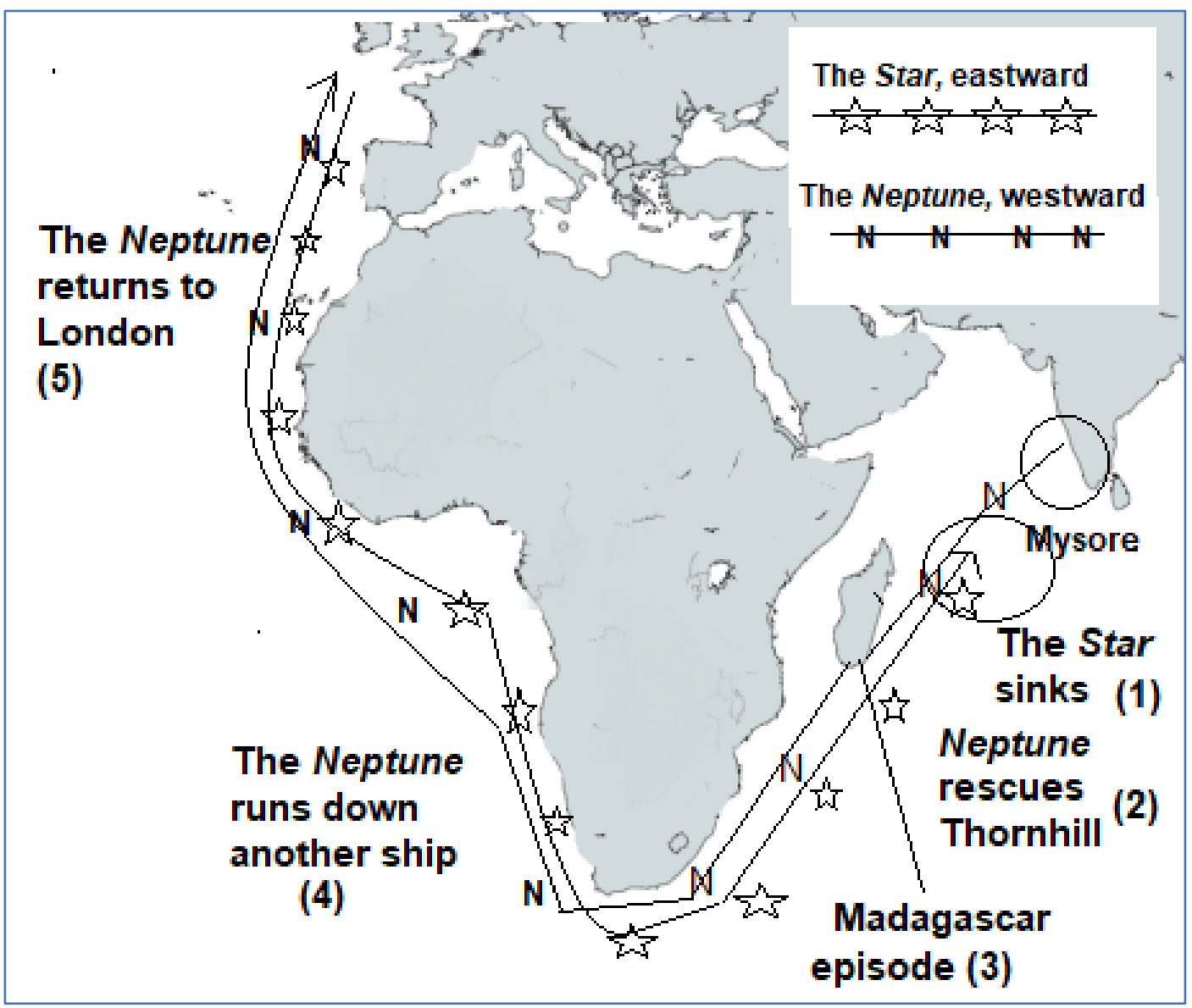

Figure 1. Voyages of the Star and the Neptune (Source: the author)

The imperial geography of the Neptune's inbound voyage also suggests ambivalence about the ethics of British imperialism in general. In two different episodes, the ship is involved in collisions that prove practically or morally hazardous to its passengers and to populations of unknown others whom they encounter in well-known colonial contact zones. The first such incident takes place shortly after Thornhill's rescue. The Neptune, caught in a storm, loses her mast and makes for Madagascar (figure 1, node 3), so that the crew may cut down a large, old tree from which to fashion a new mast: a living, wooden frontier treasure. The Neptune crew do not obtain the indigenes' permission before sawing down the tree, and a conflict develops, reminiscent of the notorious altercation between Captain James Cook and Hawaiian indigenes in 1779. During the battle, Thornhill saves Jeffery's life, justifying his own rescue but also demonstrating the dangers of colonial voyaging to EIC personnel, Indian Ocean indigenes, and their ecosystems. Then, in the Neptune's final homeward encounter, the ship is beset by fog off the coast of West Africa. Its navigators rendered blind by the fog, the Neptune frighteningly runs down (Mack 2007a: 83) another ship (figure 1, node 4). The crew and passengers of the Neptune can only watch the catastrophe in horror, as, prior to impact, it is obvious to them that "a collision was quite inevitable" (Mack 2007a: 82). They can only wonder, "fearful[ly] and agonizing[ly] ... whether the stronger vessel was of sufficient bulk and power to run them [the Neptune] down, or they it" (Mack 2007a: 82). This incident implicates the crew of the Neptune in the death of countless unknown victims, as Rymer's terrifying narration makes clear: 
[A]lmost before the echo of that cry of horror, which had come from the [Neptune's] men, had died away, the vessels met. There was a hideous crash - one shriek of dismay and horror, then all was still. The Neptune, with considerable damage, and the bulwarks stove in, sailed on; but the other ship went, with a surging sound, to the bottom of the sea ... there could be no hope of rescuing [any] one of the ill-fated crew of the ship ... and when ... they sailed out of the fog into a clear sunshine, they looked at each other like men newly awakened from some fearful dream.

(Mack 2007a: 83)

It seems not likely to be accidental that, in The String of Pearls, the ship that runs down the unknown other in the meteorological and moral fog is an EIC "Indiaman" returning from the Anglo-Mysore Wars. The EIC's entire project demolishes the colonial populations in its path.

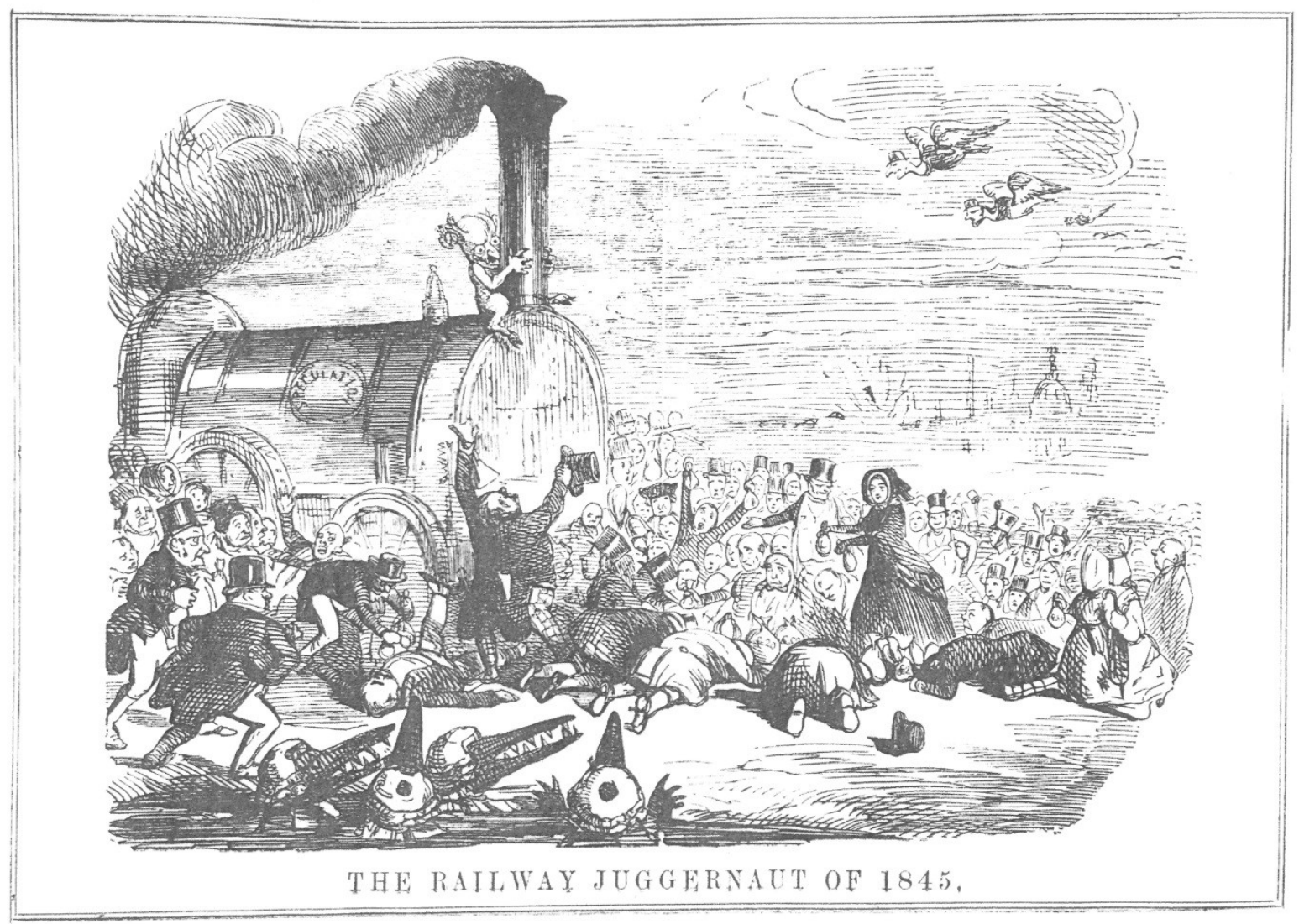

Figure 2. John Leech. 1845. “The Railway Juggernaut.” Print. Author’s Collection.

The image of the unstoppable vehicle propelled forward by its own momentum to "run down" and murder countless victims was very familiar to British readers in the 1840s. This was the essence of the early-Victorian press's idea of the "juggernaut," or Car of Jaga, the ceremonial vehicle on which the image of the Hindu deity Jaga (Krishna) was paraded at an annual festival in the Indian city of Puri. British observers had claimed that the juggernaut habitually ran down crowds of Indian worshippers, including those who deliberately threw themselves in front of its wheels. This myth horrified British readers, and evangelists and the EIC alike exploited it to justify British political, economic, and spiritual domination of India. By the 1840s, when Rymer wrote The String of Pearls, the word had become a British idiom, meaning any object or 
institution that progresses inexorably, harming or destroying its admirers and bystanders alike. An example is a Punch cartoon of 26 July 1845, John Leech's "The Railway Juggernaut," a satire of a rail industry speculation craze as, to quote critic Timothy Carens, "superstitious idolatry of industrial capitalism" (Carens 2005: 54). In the cartoon (figure 2), the juggernaut locomotive runs down a crowd of British people, sacrificing them to technological progress and corporate profit. As Carens notes, prominent British writers of the 1840s including William Makepeace Thackeray and Charlotte Brontë used juggernaut imagery to critique British home culture, and the Victorian era's "many disconcerting appearances of English juggernauts destabilise the ideologically crucial distinction between familiar imperial civilization and strange colonial otherness" (Carens 2005: 81). Consequently, by the time the juggernaut of EIC imperialism, incarnate as the Neptune, brings Jeffery, Thornhill, and the looted pearls to London (figure 1, node 5), it has taken Rymer's readers on a tour of imperialism's physical and moral hazards.

Notably, Rymer encourages his audience to imagine these voyages in cartographic terms. In the third chapter, the narration claims that "a glance at the map will be sufficient to show, that ... the nearest port at which" the crew of the Neptune "could at all expect assistance, was the British colony, at the Cape of Good Hope," but the waves instead push the ship "to the eastern coast of Madagascar" (Mack 2007a: 77-8). The "glance at the map" and the directional specificity of the line suggest that Rymer plotted this geography on at least a mental map and perhaps a physical one, and helps his readers to imagine the plot unfolding on such a map. As Sally Bushell explains, maps of the imaginary geographies of literature "enable ... gestalt understanding of an environment beyond immediate visual perception" (Bushell 2016: 125). Although Africa and India are not immediately visible from London, their mapping in the text of The String of Pearls gestures toward a gestalt understanding of British imperialism's global and metropolitan impact.

In crafting the imperial geography of The String of Pearls, Rymer specifies not only a network of places, but a very specific temporal moment that was crucial to Britain's establishment of its Indian empire. "Such was the state of things, A.D. 1785, as regarded Sweeney Todd," Rymer declares in a one-sentence paragraph midway through the first chapter (Mack 2007a: 5). In 1785, the EIC maintained a private army to protect its commercial opportunities in the Indian subcontinent, which swelled with European and Indian mercenaries, militarising and disrupting South Indian civic culture (Vartavian 2014: 288). One Indian leader who opposed EIC exploitation was the French-educated mercenary Haider Ali, who in 1761 became de facto ruler of Mysore, a city-state in India's southeastern Carnatic (Karnataka) region. Haider soon raised a significant challenge to EIC control of South India (Vartavian 2014: 489). In 1766, the EIC launched an offensive against Haider that became the First Anglo-Mysore War. The four Anglo-Mysore Wars ultimately spanned three decades and set the EIC "decisively on the road to total conquest of the Indian sub-continent" (Barua 2011: 2).

Within this era, the year 1785 was a particularly dramatic moment. The Second AngloMysore War, fought in 1780-4, saw the death of Colonel William Baillie, whom Tipu had captured after Baillie's disastrous loss of the Battle of Pollidur (1780). By 1782, the EIC strategy, if it could be called that, consisted of "ad hoc reactions to Mysore offensives" (Vartavian 2014: 40), and also involved naval battles in the Indian Ocean with Mysore's European ally, France. This naval campaign "represented a major step toward Britain obtaining a vast and vital colonial empire in India" (Barua 2011: 23). After Britain's loss of the American 
War of Independence in 1783, the stakes of the struggle with Mysore rose, offering Britain a chance to recoup face lost to the American rebels by securing a second and more economically promising overseas dominion (Barua 2011: 40). Meanwhile, the Mysorean resistance was demonised by the EIC and the British press (Brittlebank 2016: 5). The 1784 end of the Second Anglo-Mysore War - really, a temporary ceasefire - left many British prisoners in Tipu's captivity. One such imprisoned Briton, James Scurry, testifies in a posthumously published memoir (1824) that in 1785, at least a hundred such prisoners remained in Mysore and Tipu "seemed more bent on barbarities" than at "any other time that [Scurry] was in his country" (Scurry 1824: 117).

The String of Pearls quickly establishes this moment as its historical context. In the second chapter, Johanna claims that in 1783, Ingestrie had "said that he had an opportunity of making a voyage to India, and that if he were successful he should have sufficient to return with and commence some pursuit in London" (Mack 2007a: 15). This is how many of his era's entrepreneurial colonists, the nabobs - a "muddled transliteration of a title, nawab, given to highranking viceroys within the Mughal Empire" (Nechtman 2010: 71) - supposedly reasoned. As Tillman W. Nechtman notes, "there was no shortage of stories about nabobs and their Indian money," for "India, it was popularly believed, funded social nobodies and bankrupt families raising them from debt and obscurity" (Nechtman 2007: 73). In 1788, at the end of a sensational trial, the veritable king of the nabobs, Sir Warren Hastings, the orphaned child of a "fallen family" (Nechtman 2010: 73) turned EIC-appointed Governor-General of India, was impeached by the House of Lords for his rampant corruption. The Hastings affair, Saree Makdisi explains, is "one of the great 'trials of empire' and of the colonial project itself, in which Hastings' own status as the accused became less and less relevant as the proceedings dragged on" (Makdisi 1998: 111). This crisis "contributed to the development of a new kind of orientalist literature" that questioned "the economic implications of colonial practices," acknowledged "cross-cultural tensions," and confronted "imperial trauma," as experienced by colonisers, colonised, and home subjects alike (Wright 2007: 126). This literature persisted well into the Victorian era. As Carens remarks, "[i]n the Victorian period, the memory of eighteenth-century 'nabobs' who had amassed vast personal fortunes through unscrupulous trade and 'taxation' in India remained very much alive," represented by such literary figures as Thackeray's Jos Sedley (Vanity Fair, 18478), who "symbolically registers persistent guilt about England's voracious appetites for colonial territory" (Carens 2005: 124). Like Sedley, Rymer's Mark Ingestrie is a middle-class mediocrity who hopes that his Indian adventures will enable him to make his fortune, return to England, and live beyond his original station without any education, talent, or effort. According to Nechtman, the Hastings-era nabob "threatened that Britain itself could be seduced by the luxury ... that they imported into the metropolitan world" (Nechtman 2010, 91). Ingestrie's theft of the pearls and those jewels' further adventures, as they are coveted by Todd and a slew of other Britons, bears out this theory. Although Ingestrie is evidently not an EIC employee, he returns to Britain a stereotypical nabob.

The Second Anglo-Mysore War defines the world of The String of Pearls. The third chapter opens with the return to the Thames estuary of the Neptune: 
A man-of-war, which had been the convoy of the fleet of merchant-men through the channel, fired a gun as the first glimpse of the morning sun fell upon her tapering masts. Then from a battery in the neighbourhood came another booming report, and that was answered by another farther off, and then another, until the whole chain of batteries that girded the coast, for it was a time of war, had proclaimed the dawn of another day.

(Mack 2007a: 19-20)

Wester contends that "the appearance of the man-of-war foregrounds the price of material consumption through its implicit references to warfare and death" (Wester 2015: 162), but it also carries explicit historical meaning. The American Revolution having concluded in 1783, the "time of war" indicates the Anglo-Mysore Wars, during the brief cold war of 1785-6. The warship's mission is "protecting the commerce of the country": that is, EIC business (Mack 2007a: 20). Finally, some Britons en route home in the warship have been "actually rescued from the enemy" and "saved from a foreign prison" (Mack 2007a: 20); evidently Tipu's, as Scurry's memoir indicates.

\section{A Consuming Company}

Rymer complicates this ethical picture by depicting the EIC in questionable terms. He provides the Neptune with an ominous tag line, "She walks the waters like a thing of life," quoted from Byron's The Corsair, a poem about a pirate (Mack 2007a: 20). If an EIC warship recalls a pirate ship, the Company's behaviour in 1780s India might constitute piracy. Subsequent instalments of The String of Pearls develop this critique of the EIC narrative of the Anglo-Mysore Wars. For instance, Todd's association with cannibalism invites critique of EIC impact on India and London. By the late eighteenth century, that corporation had made itself "the organised body of British merchant capital," in which capacity it increasingly served as "ruler" of expanding parts of India (Mukherjee 2009: 299). According to Máire ní Fhlathúin's study of the early literature of British India (that is, the literature of the British population in Company-controlled India and, later, after the Indian Revolt of 1857-9, of the British Raj), the EIC faced "[i]ntense public debate over its role in India" (ní Fhlathúin 2015: 5). This infused imaginative literature and a wide variety of other public and private media, as anxiety about "corruption ... imported into the British body politic" via metaphors of excessive consumption, vampirism, or cannibalism (ní Fhlathúin 2015: 5). In 1799, EIC forces killed Tipu at the Battle of Seringapatam, ending the Anglo-Mysore Wars. At that point, the "metaphorical thread" imputing to Hastings and the nabobs hunger for India was so endemic that one EIC Governor-General wrote to Henry Dundas, President of the Board of Control, to suggest that the fall of Seringapatam should "stay" Dundas's "stomach" until Mornington could provide "a supper of [principalities] Oudh and the Carnatic" should Dundas "still be hungry" (quoted in ní Fhlathúin 2015: 157). In the 1820s, William Cobbett, channelling Jonathan Swift, accused the EIC of "cooking and devouring the wretched people of both England and India" (Maxwell 1903: vol. 1, 134, quoted in ní Fhlathúin 2015: 57). This imagery "reveals a prevailing anxiety about the impact of British consumption of India (literal and metaphorical) not just on India but on the consumers themselves" (ní Fhlathúin 2015: 69). It also hints that the "incorporation of the substance of India into the social and political body of ... Britain" poses a "threat to social order and national identity" (ní Fhlathúin 2015: 77); the threat with which, as Wester shows, The String of Pearls is fundamentally concerned. 
The String of Pearls likewise expresses ambivalence about the EIC in metaphors of atavistic consumption and cannibalism. A London metropolitan corporation - Sweeney Todd's dyad of companies - tempts Londoners unwittingly to commit cannibalism. At lunchtime daily, "Bell Yard, Temple Bar, becomes a scene of commotion" (Mack 2007a: 28). The food is both wondrous and rare. "The enjoyment is purely one of a physical character ... high and low, rich and poor resorted to" the pies, for "there was a flavour about them never surpassed and rarely equaled" (Mack 2007a: 29). At this point in the narrative, the reader does not yet know the pies' composition. According to the not particularly omniscient narrator, they are made of "veal and pork" (Mack 2007a: 29). Most consumers do not investigate the pies' contents' origins and so implicate themselves in Todd's enterprise. Uninterested in the details of material they voluntarily incorporate into their own bodies, they prove willing to be subsumed into Todd's enterprise, making it a key factor in their own material composition, just as their historical contemporaries made colonial products such as sugar, spices, cotton, and tea part of their daily routines and corporeal bodies. Finally, at the end of the serial, the revelation of the pies' actual contents reveals the entirety of the City ("high and low, rich and poor") to itself as ferocious cannibals. The dramatic irony that characterises the period during which the reader knows the contents of the pies but the customers do not calls attention to the hypocrisy of British stereotyping of indigenes. "Savagery was supposedly a principal cause ... savages practiced ... cannibalism, self-exterminating custom," so that "for many Victorians, the idea of taming cannibals or civilizing savages was oxymoronic: civilization was a goal that the nonwhite peoples of the world could not attain, or, at best, could only approximate as "mimic men," rendering the British imperialist "civilizing mission" post-Hastings "the ultimate justification for imperialism" (Brantlinger 2011: 1-2). Victorians thought that cannibalism ranged from Australasia to Africa and the "locus classicus" of cannibalism in the Victorian imaginary, the South Pacific, especially Fiji, an archipelago libelled since 1809 as "the Cannibal Islands" (Brantlinger 2011: 31-5). In The String of Pearls, the exposure of the denizens of Hastings-era Temple Bar as instinctive cannibals explodes the supposed moral imperative of transoceanic imperialism and likens them to the figurative India-consuming Britons who appear in the criticism of the EIC and in the company's own ephemera.

Further associating Lovett's customers with the EIC, they commit their naïve yet horrific transgression in a frontier zone. Todd and Lovett's shops occupy a liminal space between London's power nexus of City and Temple on the one hand and, on the other, the supposed "rookeries" of criminality and poverty, the inhabitants of which the press demonised in Orientalist terms as "City Arabs" (Makdisi 2016: 21). Similarly, Thomas Carlyle's Chartism (1839) compares working-class London to Africa, arguing that both are characterised by wilderness and savagery, while in Bleak House (1852-3), "Dickens contributes to the genealogy of the dark continent at home, describing London with language drawn specifically from recent accounts of philanthropic explorations in the Niger River delta" (Carens 2005: 15). Fuelling this rhetoric of metropolitan plebeian savagery was the fact that in Rymer's youth, much of London's space was cartographically unknowable. Until the $1840 \mathrm{~s}$, when the Ordnance Survey began mapping London comprehensively, "neither the British government nor any of the patchwork of local authorities in or around London possessed any truly accurate maps of the metropolitan space" (Makdisi 2016: 742). While London had obviously been represented in cartography before this, pre-Ordnance metropolitan maps tended to be "riddled with contradictions and inaccuracies, not only in terms of scale and measurement but also in that they sometimes excluded actually existing streets" (Makdisi 2016: 742). The London of this era was therefore a 
frontier zone in the eyes of many of its own inhabitants, as G. W. M. Reynolds indicated in his widely read and imitated penny novels, such as The Mysteries of London (1844-5). Furthermore, in early-nineteenth-century London, the supposed boundary between the civilised, knowable realm and its exotic opposites was Fleet Street (Makdisi 2014: 45-6). The liminality of Todd's Fleet Street barber-shop and the nearby pie shop makes it easy for him to attract bourgeois Londoners to both his businesses with a magnetism suggestive of the lure of foreign loot. The shops become portals to the East. Early nineteenth-century writing renders London "simultaneously the center of empire and a condensed or miniature version of the entire space (of empire) of which it is the center" (Makdisi 1998: 33). Rymer's relocation of atavism to the metropolis makes London "a miniature version" of the empire, the products of which it so dangerously subsumes with its returning voyagers.

Rymer's fantasy of symbolic cannibalism of India transferred to London might even be reinforced by the early-Victorian cultural connotations of Todd's unusual name, which seems to combine a legend about British cannibalism and colonisation with a surname that Victorian intellectuals associated with the EIC. Sweeney Todd's first name derives from that of Sawney Beane (Wester 2015: 156-8). According to legend, in James VI's Scotland, Beane robbed and murdered hundreds of travellers and conspired with his wife to feed the bodies to their vast horde of children and incestuously generated grandchildren. This story stokes metropolitan anxieties about colonial subjects, "other[ing] Scotland in line with" nineteenth-century England's "larger colonial project" (Wester 2015: 158), and therefore lends itself to reinvention as The String of Pearls. However, the fusion of Todd's last name with his simulation of EIC exploitation in Britain makes it plausible that he is also a namesake of James Tod (1732-1835), an EIC officer who performed topographical survey work for Hastings. Upon Tod's return to Britain, he wrote a bestselling multivolume history, Annals and Antiquities of Rajas'than (1829-32), which functions as an egregious apologia for EIC despotism. He declares the Rajput "princes ... happily rescued, by the triumph of British arms, from the yoke of lawless oppression," and India's "political connection with England ... a benefit to both parties" (Tod 1902: vii). Insisting that Britain saved Hindu India from usurpation by Muslim rulers, implicitly including Haider Ali and Tipu Sultan, Tod claims to "prove the common origin of the martial tribes of Rajasthan and those of ancient Europe," or, in other words, of "the people of the east and west" (Tod 1902: vii). Specifically, he insists that he has scientifically discovered "common origins ... of the Rajpoots and Getic tribe of Scandinavia" (Tod 1902: xiv). In other words, Britain cannot occupy India, uprooting its native culture, because Britons and Indians are modern-day versions of one ancient people. Tod may well have come to Rymer's attention, as he served as the Librarian of the Royal Asiatic Society, for which he publicly lectured on India, and in 1839, his Travels in Western India was posthumously published to great acclaim. Therefore, Sweeney Todd's name may reinforce the theme of the hypocritical EIC that consumes and disorders India and Britain.

\section{Business is Murder?}

Venturing beyond anxiety about the impact of the EIC alone, The String of Pearls calls into question the ethics of corporate business in general. The rise of the corporate body was a pressing issue in Britain from Hastings's era through the middle of the nineteenth century. The Romantic-era novel is characterised by "persistent concern about how corporate persons and collective action" can "obscure justice and accountability" (Stout 2017: 5) and conviction that despite liberalism's myth of the autonomous individual, responsibility tends to lie with 
"populations or processes" (Stout 2017: 11). The years immediately succeeding saw the emergence of the "legal fiction of the business corporation" that acts as a "corporate person," on account of legal reforms that began in the 1820s and became "fully widespread" in the 1860s (Stout 2017: 3). This phenomenon encompassed the 1837 commissioning of a Parliamentary report on the dynamics of corporate partnership and the 1841 amendment of the Factory Acts to reduce the limited liability of manufacturing companies (Stout 2017: 11). While the EIC recruited employees by suggesting that incorporation into its collective body would lead to wealth and autonomy, and promised their British customers' lives would be enhanced by exotic luxuries, Todd's incorporation of the nation into the cannibal pies implies that joining a corporation might in fact lead to the loss of personal identity, agency, and even life. As "we are what we eat," the pie shop customers, too, become monstrous corporate bodies (Brillat-Savarin [1825] 1994: 13). The incorporation of Lovett and Ingestrie into Todd's portfolio of businesses as employees distributes his blood guilt onto them.

In fact, Lovett's recruitment of Ingestrie mirrors his prior experience of incorporation. In 1783, Ingestrie enters an unnamed London-based corporation consisting of, at the very least, himself and the speculator who sends him to obtain the Indian island gold. In the Indian Ocean, he loots the pearls but loses his identity and agency. Improbably surviving the wreck of the Star, he reaches London only to find Johanna speaking with another man, Colonel Jeffery. Destitute and in despair, he begs for work at Mrs Lovett's shop, claiming he is "willing to do anything for a mere subsistence" (Mack 2007a: 92). This is the second company he willingly joins. He likens it to the Indian Ocean gold company by identifying it, correctly, as a business speculation. "[W]oe be to you, Mrs Lovett," he rails, once he learns the secret of the pies, "and all who are joined with you in this horrible speculation, at which I sicken" (Mack 2007a: 272). With this curse, he condemns not only Lovett, but "all" who belong to the same corporation. His participation in this diabolical corporation disenfranchises him more severely than his Indian Ocean adventure. He is not allowed to leave the basement manufacturing unit, is paid only in pies, and is marked for assassination as soon as he should find out the business's murderous secret or express dissatisfaction with company policy. Todd's companies make Ingestrie a cannibal, as, trapped in the cellar, he subsists upon pies and water. In twice becoming a company man, Ingestrie loses everything, including his humanity.

\section{The Victorian Tipu}

Could Rymer have expected his metropolitan mass audience to recognise the Anglo-Mysore War geography of The String of Pearls and from it to deduce a critique of the corporate ethics exemplified by the EIC? I think so. From approximately 1808 until its dissolution in 1858, the EIC maintained a public museum in London. This "East India Company Museum” or "Oriental Repository" displayed exhibits that made Tipu's domain seem luxurious and barbaric, rendering British conquest of India a moral imperative (Hibbert 2010: 261). In the 1820s-50s, as Suriya Goswami has discovered, "London guidebooks ... regularly made mention of the Company's collections ... all invoking a recurrent theme: the defeat of Tipu and the triumph of a resilient British army" (Goswami 2012: 53). The most famous artefact on display was Tipu's "ManTiger-Organ," a small pipe organ encased in a wooden tiger automaton that seems to devour a young man costumed like an EIC soldier. Allegedly, the instrument commemorates the historical 
fatal mauling of the EIC army officer Sir Henry Munro's son George. As Charles Dickens recalled, the museum also "teem[ed] with precious stuff and stones" (quoted in Bremner 2005: 735), much of it looted from Seringapatam.

Popular culture also teemed with representations of Tipu, including a few surprisingly sympathetic ones. Henry Milner's 1823 melodrama Tippoo Saib, or, The Storming of Seringapatam lionises Tipu and pities his captured children (Worrall 2008). Notably, Milner's most successful plays were performed frequently at the "minor theatres," which catered primarily to the same working-class clientele as did Lloyd's publications (Moody 2000: 115-16). Milner's Tippoo Sahib was produced at theatres of this type including Astley's Royal Amphitheatre and the Theatre at Sadler's Wells. This latter playhouse was enormous, seating over 2,000 spectators by 1860, and located in Clerkenwell: Rymer's childhood home and one of the poorest areas in nineteenth-century London (Romney; Worrall 183). Another sympathetic depiction of Tipu appears in the Christmas week 1846 number of Lloyd's People's Periodical, the paper that had just then begun its serial run of The String of Pearls. In the possibly pseudonymous Oscar Smythe's "The Twelfth-Cake Goblin: A Story for Christmas," Master Charley Bounce, Esquire, turns fourteen years old on Christmas Day. Raised among "embryo barons, knights, and 'squires residing in the neighbourhood," he is spoiled and deeply unpleasant, especially to his family's servants (Smythe 1846: 188). For Christmas and his birthday, his rich uncle sends a sumptuous iced dessert festooned with a Tipu-shaped cake topper. "That terrible fellow, Tippoo Saib, quondam a sultan of the Indies" was "enthroned upon a glorious twelfth-cake ... And what monarch would have the conscience to ask a richer dominion, I should like to know?" (Smythe 1847: 188). Not Tipu, whom Smythe transforms into a spirit of good kingship and harsh pedagogy. In a Christmas Eve dream derivative of those of Ebenezer Scrooge, the cake topper comes to life as a giant "goblin" version of Tipu, which teaches Master Charley not "to entertain too high an opinion of" his "own importance" (Smythe 1847: 189). For this story to make sense to its original readers, Tipu's fame must precede him.

Several of Rymer's own works for the same audience as "The Twelfth-Cake Goblin" and The String of Pearls indicate that he assumed his readers to possess basic knowledge of Tipu's history and the EIC's practices. Two examples survive in Rymer's privately circulated holograph scrapbook of clippings of his periodical contributions. In a short satire, a middle-class character dreams he has an uncle who "went to India," was paid in "stock in the books of the East India Company" totalling "ten thousand a-year," and left it to his nephew, making him fantastically rich and consequently evil (Rymer n.d. a: n.p.). The second piece, "Interview with a Serpent, by the Author of the Diary of a Queen's Messenger," purports to be written by an English courier of the right generation to have also witnessed, in another piece, the Battle of the Nile. "In the early part of what, without impropriety, I may call my diplomatic career, I spent some time in Southern India," his account begins:

At that time, the company was making efforts to extend its empire into remote districts, where the foot of an European had not yet trodden; and it was the custom, as it is now, to make a conquest of the territory and capital of some petty prince, and then oblige him with an English Resident, who, with a small force, resided at his court, and while leaving him the shadow of sovereignty, grasped, on behalf of the company, the substance of the kingly state. 
It was not remarkably pleasant at that time to be one of these Out Residents, as they were called. At odd times there would be a little impatience under his control, and his head would be sent as a present from one chief to another; but still there were found enterprising young men desperate adventurers, who were ever ready to accept the hazardous trust, and to penetrate far into a hostile country, to exact an authorty [sic], the only surprising thing concerning which is, that it was ever submitted to for a moment.

(Rymer n.d. b: n.p.)

Rymer launches into this fable without explaining the history of "the company's actions in India," or even what "the company" is. He simply expects his readers to know, or, rather, to possess a mental geography of the Empire in which India is already EIC territory and is indelibly marked by the Company's corruption and chaos.

\section{Wiped off the Map}

During the twentieth century, The String of Pearls may have proven too discomfiting a tool for talking about London's relationship with the Empire. The British public had not forgotten the Anglo-Mysore Wars. Winston Grahame's popular bestseller Ross Poldark: A Novel of Cornwall (1945) mentions without clarification that in the 1770s-80s, British soldiers fought "the Americans, the French, the Dutch, the Spaniards, and Hyder Ali of Mysore" (Graham 1983: 43). However, Britain was not comfortable with this history. Throughout the twentieth century, as the popularity of the character of Sweeney Todd grew, giving rise, as Erica Haugtvedt (2016) has shown, to a busy transmedial storyworld, the Indian Empire backstory gradually receded from view. George King's 1936 film Sweeney Todd, The Demon Barber of Fleet Street, a British blockbuster starring the melodramatic and appropriately named stock actor Tod Slaughter, superficially retains the original geography of The String of Pearls. In this film, sailors leave London for a vaguely defined Orient, promising to bring back tea (an Indian commodity) and "Japanese silk." Todd remarks that he likes his victims "from the Indies" (nabobs, not Indians) because "they generally have much money." Ingestrie duly delivers Johanna a string of pearls, while the point that "money makes a gentleman," as Johanna's clueless father puts it, is laboriously promoted. However, the historical context is gone. The main action takes place squarely in the Victorian era, not in the 1780s. There is no "Indian Army," no Britons released from a foreign prison, and no Colonel Jeffery, so colonisation of India has not harmed British society as indubitably as it does in The String of Pearls. King's Ingestrie is more innocent than Rymer's of complicity in the plunder of India, because he receives the pearls from a fellow English sailor, who, dying of an attack by stock African "natives," claims to have "worked all" his "life" to earn the pearls. In other words, neither this man nor Ingestrie stole them. The only indigenous people depicted in the film are unsympathetic and hardly human. These departures from Rymer's narrative enable the original British audience to savour Sweeney Todd's mayhem without reading it as a critique of their imperial history. It appeared at a climactic point in India's independence struggle, five years after Mohandas (Mahatma) Gandhi's visit to the United Kingdom, and in the year of the British Parliament's passage of the controversial Government of India Act, which increased Indian suffrage and offered nominal self-government within the existing colonial framework. When King's film is understood as a product of its time and place, it is unsurprising that its reinvention of the Sweeney Todd tradition changes course to endorse British imperialism. 
Later twentieth-century adaptations strip away even more of the topical meaning of The String of Pearls by shrinking the story's geography down to a fantastically autonomous London. In Bond's Sweeney Todd, the Demon Barber of Fleet Street, A Melodrama and Stephen Sondheim and Hugh Wheeler's 1979 Broadway musical adaptation of that play, there is no string of pearls. Ingestrie exists vestigially as the naïve sailor Anthony Hope, who claims that he has "seen ... the wonders of the East" (Bond 1974: 1). However, neither Bond nor Sondheim ever suggests that there are any ties between this amorphous "East" and London. Both plays incorporate a colonial location in that Sweeney Todd escapes from Australia but depict that continent only as a prison, not an inhabited space whose indigenous population British colonisation decimated. In these variations of the Sweeney Todd legend, the colonial geography that is essential to Rymer's serial completely vanishes, leaving an insular London not affected by, nor affecting, the people of the British Empire's colonised spaces. This evolution of the story suggests that evisceration of provocative or disturbing political subtexts might even be a type of re-mapping of stories that popular culture regularly performs. Reconstruction of the political geography of The String of Pearls with respect to EIC history reveals that text as a tool for talking not just about London, the EIC, and the ethics of corporate business, but also about the capacity of transmedia storytelling to re-map those imaginary geographies that seem to mirror the world rather too well.

\section{Bibliography}

Barua, Pradeep P. 2011. "Maritime Trade, Seapower, and the Anglo-Mysore Wars, 1767-1799." Historian, 73.1: 22-4.

Bond, Christopher G. 1974. Sweeney Todd, the Demon Barber of Fleet Street, a Melodrama. New York: Samuel French.

Brantlinger, Patrick. 2003. Dark Vanishings: Discourse on the Extinction of Primitive Races, 1800-1930. Ithaca and London: Cornell University Press.

Brantlinger, Patrick. 1988. Rule of Darkness: British Literature and Imperialism, 1830-1900. Ithaca: Cornell University Press.

Brantlinger, Patrick. 2011. Taming Cannibals: Race and the Victorians. Ithaca: Cornell University Press.

Bremner, G. Alex. 2005. "Nation and Empire in the Government Architecture of Mid-Victorian London: The Foreign and India Office Reconsidered." Historical Journal, 48.3: 703-42.

Brillat-Savarin, Jean-Anthelme. [1825] 1994. The Physiology of Taste, edited by Anne Drayton. Harmondsworth: Penguin.

Brittlebank, Kate. 2016. Tiger: The Life of Tipu Sultan. New Delhi: Juggernaut.

Bushell, Sally. 2016. "Mapping Fiction: Spatializing the Literary Work." In Literary Mapping in the Digital Age, edited by David Cooper, Christopher Donaldson, and Patricia Murrieta-Flores, 12546. New York: Routledge.

Carens, Timothy. 2005. Outlandish English Subjects in the Victorian Domestic Novel. New York: Palgrave Macmillan.

Carroll, David. 1997. "Master Shaper: An Interview with Neil Gaiman.” First published in Blood Songs 8 (1997), reprinted at http://www.tabula-rasa.info/AusComics/NeilGaiman.html. Accessed 22 December 2019. 
Collins, Dick. 2010. "Introduction to the Revised Edition." In The String of Pearls, by James Malcolm Rymer, edited by Dick Collins, v-xxx. Ware: Wordsworth.

"Curiosities of Crime: The Barber Fiend." 1866. London Miscellany, 1.15: 239.

"Description of Tippoo Sultan's Zenana." 1800. Lady's Monthly Magazine, (1 January) 11.

Dickens, Charles. [1842] 1899. Martin Chuzzlewit. New York: Charles Scribner's Sons.

ní Fhlathúin, Máire. 2015. British India and Victorian Literary Culture. Edinburgh: Edinburgh University Press.

Geier, Ted. 2017. Meat Markets: The Cultural History of Bloody London. Edinburgh: Edinburgh University Press,.

Goswami, Supriya. 2012. Colonial India in Children's Literature. London: Routledge.

Graham, Winston. [1945] 1983. Ross Poldark: A Novel of Cornwall. Oxford: The Bodley Head.

Hackenberg, Sara. 2019. "Romanticism Bites: Quixotic Historicism in Rymer and Reynolds." In Edward Lloyd and his World: Popular Fiction, Politics, and the Press in Victorian Britain, edited by Sarah Louise Lill and Rohan McWilliam, 165-82. New York: Routledge.

Haugtvedt, Erica. 2016. "Sweeney Todd as Victorian Trasmedial Storyworld." Victorian Periodicals Review, 49.3: 443-60.

Hazlitt, William. [1821] 1903. Table-Talk: Essays on Men and Manners. London: G. Richards.

Hibbert, Christopher, Ben Weinreb, John Keay, and Julia Keay. 2010. The London Encyclopaedia, $3^{\text {rd }}$ ed. Houndsmills: Macmillan.

“The India-House Museum.” 1851. Child's Companion, 145.77 (1 May): 1-6.

James, Louis. 2019. “'I am Ada!': Edward Lloyd and the Creation of the Victorian 'Penny Dreadful.” In Edward Lloyd and his World: Popular Fiction, Politics, and the Press in Victorian Britain, edited by Sarah Louise Lill and Rohan McWilliam, 54-70. New York: Routledge.

Léger-St-Jean, Marie. 2002-19. Price One Penny: A Database of Cheap Literature, 1837-1860. Faculty of English, Cambridge. http://priceonepenny.info. Accessed 5 September 2019.

Mack, Robert L., ed. 2007a. Sweeney Todd: The Demon Barber of Fleet Street. Oxford: Oxford University Press.

Mack, Robert L. 2007b. The Wonderful Adventures of Sweeney Todd: The Life and Times of an Urban Legend. London: Continuum.

Makdisi, Saree. 2014. Making Britain Western: Occidentalism, Race, and Imperial Culture. Chicago: University of Chicago Press.

Makdisi, Saree. 1998. Romanticism and Imperialism: Universal Empire and the Culture of Modernity. Cambridge: Cambridge University Press.

Makdisi, Saree. 2016. "William Blake, Charles Lamb, and Urban Antimodernity." Studies in English Literature, 56.4: 737-56.

Marshall, P. J. 1992. "Cornwallis Triumphant: War in India and the British Public in the Late 18th Century." In War, Strategy and International Politics: Essays in Honour of Sir Michael Howard, edited by Laurence Freedman et al., 57-74. Oxford: Clarendon.

Maxwell, Herbert, ed. 1903. The Creevey Papers: A Selection from the Correspondence \& Diaries of the Late Thomas Creevey, M.P. 2 vols. London: John Murray.

McWilliam, Rohan. 2019. "Sweeney Todd and the Chartist Gothic: Politics and Print Culture in Early Victorian Britain." In Edward Lloyd and his World: Popular Fiction, Politics, and the Press in Victorian Britain, edited by Sarah Louise Lill and Rohan McWilliam, 198-215. New York: Routledge. 
Moody, Jane. 2000. Illegitimate Theatre in London, 1770-1840. Cambridge: Cambridge University Press.

Mukherjee, Ramkrishna. 2009. The Rise and Fall of the East India Company: A Sociological Appraisal, edited by Roopali Mukherjee. New York: Monthly Review Press.

Nechtman, Tillman W. 2007. "A Jewel in the Crown: Indian Wealth in Domestic Britain in the Late Eighteenth Century." Eighteenth-Century Studies, 41.1: 71-86.

Nechtman, Tillman W. 2010. Nabobs: Empire and Identity in Eighteenth-Century Britain. Cambridge: Cambridge University Press.

Ramsay, Neil. 2007. "Horrid Scenes and Marvellous Sights: The Citizen-Soldier and Sir Robert Ker Porter's Spectacle of War." Romanticism on the Net, 46. https://www.erudit.org/en/journals/ron /2007-n46-ron1782/016132ar/. Accessed 9 June 2019.

Romney, J. 1829. The Storming of Seringapatam, or, the Death of Tippoo-Saib! [Poster]. London. Victoria and Albert Museum. Gabrielle Enthoven Collection, accession no. S.23-1998.

Rymer, James Malcolm. n.d. a. "A Fright, or What Mr. Hallerton Wiggles Did with Ten Thousand aYear.” In Tales \& Sketches. Holograph scrapbook. 2 vols, item 3. British Library.

Rymer, James Malcolm. n.d. b. "Interview with a Serpent.” In Tales \& Sketches. Holograph scrapbook. 2 vols, item 27. British Library.

Said, Edward W. 1978. Orientalism. London: Routledge and Kegan Paul.

Scalercio, Mauro. 2016. "The Italian Job: Giambattista Vico at the Origin of Edward Said's Humanism." Sanglap: Journal of Literary and Cultural Inquiry, 3.1. http://sanglap-journal.in /index.php/sanglap/article/view/136/160. Accessed 9 June 2019.

Schoenfield, Mark. 2009. British Periodicals and Romantic Identity: The "Literary Lower Empire." New York: Palgrave Macmillan.

Scurry, James. 1824. The Life of James Scurry, Seaman. London: Henry Fisher.

The Sepoy's Daughter, A True Tale of the Indian War, By an Eye Witness. 1860. London: Henry Lea.

Smith, Helen R. 2002. New Light on Sweeney Todd, James Malcolm Rymer, Thomas Peckett Prest, and Caroline Elizabeth Grey. London: Jarndyce.

Smith, Helen R. 2019. "Edward Lloyd and his Authors." In Edward Lloyd and his World: Popular Fiction, Politics, and the Press in Victorian Britain, edited by Sarah Louise Lill and Rohan McWilliam, 39-53. New York: Routledge.

Smythe, Oscar. 1846. "The Twelfth-Cake Goblin: A Story for Christmas." People's Periodical and Family Library, 1.2: 188-9.

Sondheim, Stephen and Hugh Wheeler. 2012. Sweeney Todd, the Demon Barber of Fleet Street: A Musical Thriller. Falls Church, VA: Rilting Music.

Stout, Daniel M. 2017. Corporate Romanticism: Liberalism, Justice, and the Novel. New York: Fordham University Press.

Sweeney Todd, The Demon Barber of Fleet Street. 1936. Dir. George King. With Tod Slaughter. London: George King Productions.

Tod, James. 1902. Annals and Antiquities of Rajasthan, or, the Central and Western Rajpoot States of India. 3 vols. Calcutta: Society for the Resuscitation of Indian Literature.

Untitled. 1857. Building News, (22 May) 502.

Vargo, Gregory. 2018. An Underground History of Early Victorian Fiction: Chartism, Radical Print Culture, and the Social Problem Novel. Cambridge: Cambridge University Press. 
Vartavarian, Mesrob. 2014. "An Open Military Economy: The British Conquest of South India Reconsidered, 1780-1799." Journal of the Economic and Social History of the Orient, 57.4: 486510.

Wester, Maisha. 2015. "Text as Gothic Murder Machine: The Cannibalism of Sawney Beane and Sweeney Todd." In Technologies of the Gothic in Literature and Culture: Technogothics, edited by Justin Edwards, 154-65. New York: Routledge.

Worrall, David. 2008. "Islam on the Romantic Period Stage: Hyder Ali, Tippoo Saib, and Beyond the Captivity Narrative." In Unrespectable Radicals? Popular Politics in the Age of Reform, edited by Paul A. Pickering and Michael Davis, 167-84. London: Routledge.

Wright, Julia M. 2007. Ireland, India and Nationalism in Nineteenth-Century Literature. Cambridge: Cambridge University Press. 